\title{
KEMAPANAN SISTEM DEMOKRASI DI INDONESIA (Antara Demokrasi Islam Versus Demokrasi Barat) (Review)
}

\author{
Irwan Djumat
}

\author{
${ }^{1}$ Dosen Program studi Pendidikan Pancasila dan Kewarganegaraan FKIP Unkhair
}

Email: irwandjumat@yahoo.com

$\begin{array}{ll}\text { Diterima } & : 08-02-2019 \\ \text { Direvisi } & : 25-03-2019 \\ \text { Dipublikasi } & : 01-05-2019\end{array}$

\begin{abstract}
Abstrak. Demokrasi kini telah menjadi bagian terpenting dari kehidupan manusia. Demokrasi sebagai suatu sistem telah dijadikan alternatif dalam berbagai tatanan aktifitas kehidupan bermasyarakat dan bernegara. Terdapat dua alasan dijadikannya demokrasi sebagai sistem bermasyarakat dan bernegara, Pertama, hampir semua negara di dunia ini telah menjadikan demokrasi sebagai asas yang fundamental; kedua, demokrasi sebagai asas kenegaraan secara esensial telah memberikan arah bagi peranan masyarakat untuk menyelenggarkan negara sebagai organisasi tertingginya. Dalam prakteknya di Indonesia masih terbelenggu oleh demokrasi Islam ataukah Barat. Namun demikian intin dari demokrasi adalah dari rakyat, oleh rakyat dan untuk rakyat. Artinya pemerintahan memberikan penekanan pada keberadaan kekuasaan di tangan rakyat, baik dalam penyelenggaraan negara maupun pemerintahan. Kekuasaan pemerintahan berada di tangan rakyat mengandung arti; pertama, pemerintahan dari rakyat (goverment of the people) mengandung pengertian yang berhubungan dengan pemerintahan yang sah dan diakui (legitimate government); kedua, pemerintahan oleh rakyat (goverment by people), yakni suatu pemerintahan yang menjalankan kekuasaan atas nama rakyat, bukan atas dorongan dan keinginan sendiri; ketiga, pemerintahan untuk rakyat (government for the people), mengandung pengertian bahwa kekuasaan yang diberikan oleh rakyat kepada pemerintah harus dijalankan untuk kepentingan rakyat.
\end{abstract}

Kata Kunci: Sistem, demokrasi Indonesia, demokrasi Islam, demokrasi Barat

\section{PENDAHULUAN}

Topik di atas adalah pergumulan penulis yang merupakan sebuah anti tesis tatkala membaca kondisi perjalanan bangsa dalam berdemokrasi dari tahun ke tahun, terhitung sejak lengsernya Soeharto tahun 1998. Di awal abad 21 ini, telah terjadi perubahan yang sangat cepat dan besar-besaran dalam tatatanan kehidupan ekonomi global. Kemajuan ilmu pengetahuan, teknologi, dan komunikasi yang sebagian besar dikuasai oleh non muslim menjadikan dunia ini terasa seperti bola pingpong. Tidak ada lagi sekatsekat antara Barat dan Islam, bahkan di kancah politik global, umat Islam sangat terpojokkan dan menjadi bulan-bulanan oleh AS dan sekutunya beserta dedengkot-dedengkot Yahudi. Hal ini berdampak pada lahirnya paham Radikalisme yang menjadi senjata pemusnah massal dan dijadikan simbol sebagai alasan untuk melakukan kekerasan dan peperangan dalam rangka menarik simpati para pemimpin dunia.

Kemarahan global pun muncul, di satu sisi AS dan sekutunya dituding sebagai penghancur peradaban manusia, di sisi lain penganut Islam garis keras yang selama ini ditindas dan diisukan sebagai teroris. Terjadilah pro dan kontra antara Barat dan Islam tentang terorisme, yang pada kesimpulannya penganut Islam harus mengalah dan sepakat untuk memerangi terorisme lantas kemudian merancang UU anti terorisme tanpa mendudukkan persoalan yang sesungguhnya, siapa yang teroris?.

Banyak cara yang mereka lakukan untuk melemahkan umat Islam, hak asasi manusia mereka balut sedemikian rupa sehingga tidak tampak bahwa ada penindasan. Jean Baudrillad dalam the Perfect Crime (1995), menyebut the perfect crime (kejahatan sempurna) sebagai sebuah "penggelapan" dan "pemerkosaan realitas". Kejahatan yang menyembunyikan dirinya secara sempurna dan secara halus, ia tidak pernah dapat diketahui ataupun diungkapkan dibalik teriaknya tentang hak asasi manusia, sehingga tidak tampak seperti sebuah kejahatan. 
Kejahatan sempurna adalah kejahatan yang berada dibalik aroma nilai-nilai moral, kemanusiaan dan perdamaian universal. Kejahatan seperti: teror, agresi, intimidasi, provokasi, dan disinformasi yang sering dengan sangat halus dilakukan oleh kaum Barat khususnya Amerika Serikat terhadap sebuah Negara berdaulat. Indonesia pun mengalaminya atas nama penegakan hak asasi manusia, perdamaian, dan demokrasi (Pilliang, 1999).

Demokrasi mereka gaungkan sudah sejak lama untuk menata sebuah Negara seperti juga Indonesia yang kedaulatannya konon berada di tangan rakyat. Demokrasi sebagai suatu sistem telah dijadikan alternatif dalam berbagai tatanan aktifitas kehidupan bermasyarakat dan bernegara. Menurut Mahfud MD, terdapat dua alasan dijadikannya demokrasi sebagai sistem bermasyarakat dan bernegara. Pertama, menurut Mahfud, hampir semua negara di dunia ini telah menjadikan demokrasi sebagai asas yang fundamental; kedua, demokrasi sebagai asas kenegaraan secara esensial telah memberikan arah bagi peranan masyarakat untuk menyelenggarkan negara sebagai organisasi tertingginya.

Dikatakan oleh Azyumardi Azra (2005: ix), transisi Indonesia menuju demokrasi sejak jatuhnya Presiden Soeharto pada 21 Mei 1998 dari kekuasaan yang dipegangnya selama lebih dari 30 tahun tidak mungkin lagi dimundurkan (poin of no retun). Setelah lebih dari tiga dasawarsa berada di bawah kekeuasaan represif, Indonesia mengalami liberalisasi politik dan demokratisasi. Hasilnya Indonesia kini mulai disebut-sebut sebagai salah satu negara demokrasi tebesar di dunia, atau disebut dengan third largest democracy in the world, setelah India dan Amerika Serikat.

Bagaimanakah sesungguhnya sistem demokrasi di Indonesia, apakah mempraktekkan sistem demokrasi Islam atau demokrasi Barat?

\section{PEMBAHASAN}

\section{Gaung Demokrasi}

Berbicara tentang demokrasi sesungguhnya tidak lepas dari eksistensi manusia sejak manusia dihadirkan di muka bumi ini, demokrasi sudah digagas dan diperbincangkan. Teringat oleh kita tentang diciptakannya manusia oleh Allah swt sebagai khalifah sangat ditentang oleh para jin, bagaimana mengangkat pemimpin yang nantinya memunculkan pertumpahan darah. Sejak peristiwa ini terjadi, demokrasi seakan tidak pernah tuntas dibahas sejak diperkenalkan lewat kata demos dan cratein pada era city state (Negara-kota) di Yunani pada zaman Pericles di abad keempat dan kelima. Demokrasi terdiri dari dua kata yang berasal dari bahasa Yunani yaitu "demos" yang berarti rakyat atau penduduk suatu tempat dan "cratein" atau "cratos" yang berarti kekuasaan atau kedaulatan. Demokrasi adalah keadaan negara di mana sistem kedaulatannya berada di tangan rakyat, kekuasaan tertinggi berada dalam keputusan bersama rakyat, rakyat berkuasa, pemerintahan rakyat dan kekuasaan oleh rakyat. Sementara itu Gaffar (2000) memaknai demokrasi dalam dua bentuk, pemaknaan secara normatif (demokrasi normatif) dan empirik (demokrasi empirik). Menurutnya demokrasi normatif adalah demokrasi yang secara ideal hendak dilakukan oleh sebuah negara. Sedangkan demokrasi empirik adalah demokrasi dalam perwujudannya pada dunia politik praktis.

Hakikat demokrasi sebagai suatu sistem bermasyarakat dan bernegara, serta pemerintahan memberikan penekanan pada keberadaan kekuasaan di tangan rakyat, baik dalam penyelenggaraan negara maupun pemerintahan. Kekuasaan pemerintahan berada di tangan rakyat mengandung arti: pertama, pemerintahan dari rakyat (goverment of the people) mengandung pengertian yang berhubungan dengan pemerintahan yang sah dan diakui (legitimate government) kedua, pemerintahan oleh rakyat (goverment by people), yakni suatu pemerintahan yang menjalankan kekuasaan atas nama rakyat, bukan atas dorongan dan keinginan sendiri. ketiga, pemerintahan untuk rakyat (government for the people), mengandung pengertian bahwa kekuasaan yang diberikan oleh rakyat kepada pemerintah harus dijalankan untuk kepentingan rakyat (Tim ICCE UIN Jakarta, 2015: 111-112). Artinya manusia atau rakyat betul-betul dihargai harkat dan kedudukan dalam masyarakat oleh pemerintah yang menjalankan demokrasi. 
Seperti halnya Barat dengan pandangan antroposentris memiliki beberapa nilai utama, yaitu demokrasi itu sendiri, institusi sosial, dan kesejahteraan ekonomi yang berpokok pangkal pada penghargaan mutlak tehadap manusia. Demokrasi didasarkan pada filsafat tentang manusia sebagai sumber nilai dan kepercayaan, bahwa rakyat jelata sanggup memutuskan dan memilih untuk kepentingan umum. Kenyataan akan nilai dan keagungan individu dengan segala keterbatasannya adalah dasar paling dalam dan pusat dari demokrasi. Deklarasi kemerdekaan Amerika (1776) misalnya menyatakan:...,bahwa semua manusia diciptakan sama, dilengkapi pencipta dengan hak-hak yang tidak dapat digugat, antara lain, hidup, kebebasan, dan uasaha untuk kebahagiaan (Soelaeman, 2001: 155). Kenyataannya justru berbalik, Amerika menjadi sangat diktator dalam memainkan peran di dunia pasca runtuhnya Negara komunis Soviyet, demokrasi mereka usung dengan dalil kebebasan tetapi penindasan pun mereka jalankan.

Chester E. Finn Jr, guru besar pendidikan dan kebijakan umum Universitas Vanderbilt juga sebagai direktur Educational Execellence Network dalam sebuah pidatonya di hadapan para pendidik dan pejabat pemerintah di Managua Nikaragua, mengatakan "manusia secara alamiah memilih kebebasan ketimbang penindasan adalah hal yang sangat wajar, tetapi tidak sama dengan sistem politik yang menginginkan demokrasi dapat tercipta dan mempertahankan dirinya sepanjang masa. Sebaliknya gagasan tentang demokrasi itu langgeng tetapi prakteknya sulit" (Prayitno, 2001: 3), karena yang mengotaki demokrasi adalah manusia dengan segala kepentingannya sehingga arah demokrasi sulit untuk diterka.

Bahkan Demokrasi itu sendiri tidak menjamin apa-apa, sebaliknya ia menawarkan kesempatan untuk menuai keberhasilan serta menerima resiko kegagalan. Seperti yang pernah diucapkan oleh Thomas Jefferson, bahwa janji demokrasi adalah hidup, kemerdekaan, dan pengejaran kebahagiaan. Ia mengatakan, demokrasi adalah janji sekaligus tantangan. Ia menjanjikan, bahwa manusia yang bebas, bekerja sama, dapat melayani masyarakat, kesempatan dalam menjalankan ekonomi, dan keadilan sosial. Demokrasi juga merupakan tantangan karena keberhasilannya bertumpu pada pundak warga negaranya sendiri dan bukan pada orang lain. Dalam setiap masyarakat dan setiap generasi yang tumbuh silih berganti harus memiliki kepedulian untuk memperbaharui demokrasi, mengambil prinsip-prinsip masa lalu dan menerapkannya dalam berbagai praktek, serta tidak menyalahkan orang lain yang mendahuluinya. Josef Brodsky, pujangga kelahiran Rusia dan pemenang hadiah nobel pernah menulis "orang yang bebas jika tidak menyalahkan siapapun" (Prayitno, 2001: 31). Itu juga berlaku bagi orangorang yang mengusung demokrasi yang akhirnya harus memikul tanggung jawab terhadap nasib masyarakat yang telah memilih mereka.

\section{Arah Demokrasi Indonesia Islam Versus Barat}

Di Indonesia, kita sulit untuk menentukan bagaimana arah demokrasi yang sesungguhnya karena diperhadapkan pada pemikiran Islam versus Barat, terutama bidang ideologi politik khususnya tentang demokrasi itu sendiri. Setidaknya terdapat tiga kelompok sikap. Pertama, kelompok yang melakukan imitasi bahkan subtitusi secara total. Bagi mereka tidak ada jalan lain bagi umat Islam bila ingin maju kecuali mengambil ideologi Barat (demokrasi) secara utuh. Hal ini sebagaimana pernah dilakukan oleh Kemal Pasha dan sebagian besar penguasa negeri Muslim sekarang ini. Bagi mereka ideologi Islam dianggap sebagai penghambat kemajuan, bahkan ancaman. Kedua, kelompok yang melakukan pemblasteran (perkawinan) antara konsep barat dan Islam. "sosialisme Islam", "Theodemokrasi" dan sebagainya adalah sebagian istilah yang muncul dari hasil upaya tersebut, tidak jarang kita mendengar ungkapan: "Islam itu, ya demokrasi itu sendiri". Bahkan Tuhan juga sangat demokratis, mereka menganggap dengan cara ini, Islam akan lebih muda diterima dan mampu menjawab tantangan zaman. Ketiga, kelompok yang menolak sama sekali ideologi Barat, bagi mereka Islam is Islam. Di bidang peristilahan pun menurut mereka, Islam tidak tergantikan. Ideologi Islam hanya bisa dijelaskan dengan istilah yang berasal dari khazanah Islam itu sendiri. Bagi mereka menjelaskan Islam dengan peristilahan yang muncul dari Barat hanya akan mengaburkan dan menghilangkan esensi pemikiran Islam itu sendiri (Yusanto, 1998: 101). Bahkan bukan saja Islam yang menjadi ancaman bagi Barat seperti yang dikatakan oleh Samuel Hungtinton dalam kegelisahannya juga mempertimbangkan Cina dalam tesisnya 
tentang The Clash of Civilizations. Menurutnya, Cina adalah salah satu aktor selain Islam yang akan berbenturan dengan peradaban Barat yang demokratis dan kapitalis.

Di sisi lain, ada juga kaum nasionalis religius yang sangat antusias terhadap demokrasi. Bahkan kaum aktivis yang sangat menentang Negara sekuler pun menggenggam erat pentingnya semangat demokrasi dalam politik. Syaikh Yassin misalnya mengatakan, bahwa "Islam meyakini demokrasi". Seorang anggota Ikhwanul Muslimin di Mesir mengatakan " demokrasi adalah satu-satunya sistem bagi Negara Islam", begitupula seorang pemimpin Gush Emunim Israel mempunyai nada yang sama, bahwa "kami butuh demokrasi meski dalam sebuah masyarakat religius". Kaum nasionalis religius Asia Tengah pun menyuarakan keinginan pada demokrasi dalam suatu Negara religius.

Beberapa antusiasme ini memberikan makna tersendiri kepada demokrasi. Apabila demokrasi bermakna kekuasaan mayoritas, maka ia akan membiarkan rakyat memilih apa yang mereka inginkan, dan apabila rakyat menginginkan suatu masyarakat religius maka merekapun memilihnya (Juergenmeyer, 1993: 205).

Tidak dapat dipungkiri, demokrasi kini telah menjadi suatu ideologi yang paling luas pengikutnya, termasuk di Nagari-nagari Islam. Demokrasi dipercayai mereka sebagai suatu ideologi yang diyakini dapat menghantarkan kepada tatanan masyarakat yang egalitarian, adil, dan sejahtera. Kepercayaan terhadap sistem demokrasi semakin menjadi-jadi setelah kebangkrutan sistem totaliter-komunis dibekas Uni Sovyet dan Eropa Timur, maka demokrasilah alternatif tunggal sebagai pengantinya. Pendapat ini tentunya sangat fatal dan tidak bertanggung jawab, karena keduanya sesungguhnya mengandung cacat asasi sejak lahirnya. Keduanya merupakan ideologi yang tidak mengindahkan nilai-nilai keagamaan dalam pengaturan kehidupan masyarakat. Menurut Ismail Yusanto mereka bersandar pada beberapa paham, di antaranya:

1. Kedaulatan Rakyat. Artinya bahwa yang memiliki kehendak (yamlukul Iradah) adalah rakyat. Pemerintah tegak "dari, oleh, dan untuk rakyat". Dari rakyat berarti penguasa (eksekutif) adalah pemegang mandat rakyat untuk melaksanakan kehendak-kehendaknya.

2. Pengambilan Keputusan. Dalam setiap masalah, keputusan diambil dengan musyawarah baik dengan mufakat ataupun voting, dan yang menang adalah pihak mayoritas.

3. Hak Asasi Manusia. Ide kedaulatan rakyat hanya mungkin tegak dalam masyarakat penganut paham kebebasan (alhurriyah), khususnya kebebasan beragama. Seseorang boleh beragama apa saja, tidak beragama pun boleh. Agama dipandang sebagai urusan individu dengan Tuhannya saja dan hukum Tuhan hanya berlaku untuk yang bersangkutan.

4. Pembagian Kekuasaan (power sharing). Dalam demokrasi, kekuasaan Negara dibagi menjadi kekuasaan eksekutif (kabinet), legislatif (parlemen), dan Yudikatif (kehakiman). Hal ini dimaksudkan agar tidak terjadi penumpukan kekuasaan di tangan satu orang yang akan mendorongnya menjadi diktator

5. Pemilu. Pemilihan umum baik untuk memilih presiden dan wakil presiden atau pun anggota parlemen yang diadakan dengan anggapan, bahwa hal tersebut merupakan bentuk partisipasi rakyat sebagai pemilik kedaulatan secara langsung dalam menentukan corak pemerintahannya.

Menyangkut dengan pemilu, A. M. Fatwa menjelaskan, bahwa pelaksanaan pemilu sebagai sarana berdemokrasi diharapkan mampu menghentikan prilaku politik negatif guna memperbaiki kondisi bangsa karena tujuan yang diharapkan dari pelaksanaan pemilu adalah: (1) merupakan mekanisme yang dapat memindahkan konflik kepentingan dari kelompok masyarakat kepada badan-badan perwakilan melalui wakil-wakil rakyat yang terpilih atau melalui parta-partai politik yang memenangkan kursi sehingga integrasi dan integritas masyarakat tetap terjamin; (2) sebagai mekanisme menyeleksi para pemimpin pemerintahan dan berbagai alternatif kebijakan umum; dan (3) sebagai sarana memobilisasi dan menggalang dukungan rakyat terhadap Negara dan pemerintahan dengan jalan ikut serta dalam proses politik (Fatwa, 2002: 43). Namun ketika menjadi pejabat justeru para politisi lupa akan janji-janji yang pernah diucapkan saat berkampanye. Banyak terjadi ketimpangan di berbagai bidang, baik ekonomi, pendidikan, sosial, dan politik itu sendiri. Fenomena yang sangat mengerikan di depan mata kita adalah fenomena sosial, di mana meningkatnya angka kemiskinan, kebodohan, ketidak adilan, 
korupsi yang terus marajalela, pengangguran, dan sejumlah permasalahan lainnya yang kerap mendera bangsa ini. Jikalau demikian, dimana sesungguhnya demokrasi yang diidam-idamkan?

Dalam suatu kesempatan, petisi 24 Oktober 1973 mengingatkan kepada bangsa ini, bahwa dengan kesadaran penuh akan tanggung jawab di hari depan, yang keadaannya akan sangat ditentukan oleh masa kini, dan kami adalah sebahagian dari padanya merasa berkewajiban untuk mengingatkan pemerintah, militer, teknokrat, politisi untuk hal-hal sebagai berikut:

1. Meninjau kembali strategi pembangunan dan menyusun strategi baru yang di dalamnya terdapat keseimbangan di bidang-bidang sosial, politik, dan ekonomi yang anti kemiskinan, kebodohan, dan ketidak adilan.

2. Segera membebaskan rakyat dari cekaman ketidakpastian dan pemerkosaan hukum, marajalelanya korupsi, penyelewengan kekuasaan, kenaikan harga dan pengangguran.

3. Lembaga-lembaga penyalur pendapat rakyat harus kuat dan berfungsi serta pendapat masyarakat harus mendapat tempat dan kesempatan yang seluas-luasnya (Al-Mandari, 2003: xiv).

Hal Ini hanya sekedar mengingatkan dan bukan bermaksud menyalahkan, karena di pundak mereka terdapat masa depan masyarakat dan bangsa yang sering mengalami keguncangan. Ruslan Abdulgani mengatakan, setiap masyarakat dimanapun letaknya di dunia ini selalu mengalami getaran. Kadangkala intensitas getaran itu meningkat, kadangkala menurun. Itu akibat hukum dinamika dan dialektika yang berwatak alamiah. Seperti halnya masyarakat dan Negara kita sejak beberapa tahun belakangan ini sedang mengalami suatu proses transisi dan transformasi dari masyarakat yang otoriter-tertutup kearah masyarakat demokratis-terbuka yang masih menderita krisis multi dimensional di berbagai bidang, dan bahkan lebih parah lagi adalah krisis di bidang moral dan etika (Abdulgani, 2003).

\section{KESIMPULAN}

Sejak Indonesia merdeka tahun 1995 telah terjadi pasang surut dalam sistem demokrasi di Indonesia. Mungkin karena situasi inilah kemudian bangsa ini mulai belajar untuk mengenal yang namanya demokrasi, menghargai hak-hak orang, kemerdekaan berpolitik, dan yang lainnya walaupun masi tertatih-tatih. Tetapi paling tidak demokrasi di Indonesia sudah mulai menemui titik terang, tetapi antara kekuasaan ditangan rakyat dan kekuasan ditangan pemerintah masih perlu untuk diperdebatkan. Demokrasi kita arahnya belum menentu karena diperhadapkan pada berbagai kepentingan yang diusung oleh partai-partai politik di Indonesia, antara demokrasi Islam ataukah Barat. Pada tahun 2004 misalnya, kita bangsa Indonesia telah memasuki babak baru sejarah demokrasi dengan menghasilkan Susilo Bambang Yudoyono dan H. Muhammad Yusuf Kalla sebagai presiden dan wakil presiden. Setelah itu Era SBY dan Boediono tahun 2009-2014, kemudian Era Joko Widodo dan Yusup Kalla tahun 2014-sekarang. Mereka dipilih secara langsung di tengah kondisi ekonomi bangsa yang carumarut, pengangguran di mana-mana, korupsi merajalela, kerusuhan sosial berbau SARA, penggusuran di sana sini, pelanggaran hak asasi manusia, terorisme hingga hilangnya kepercayaan masyarakat terhadap citra kepolisian RI menjadi wacana publik yang teragenda, yang dalam aspek rasionalitas telah menciderai sistem demokrasi yang di bangun di Indonesia. Dari, oleh, dan untuk rakyat adalah misi utama demokrasi yang harus terus diperjuangkan.

\section{DAFTAR BACAAN}

Abdulgani, H. Roeslan. (2000). Fitnah. dalam Rakyat Merdeka, edisi Jumat 5 Mei 2000/30 Muharram 1421 H.

Al-Mandari, Syafinuddin. (2003). HMI dan Wacana Revolusi Sosial, Jakarta: Hijau Hitam.

Gaffar, Affan (2000). Politik Indonesia: Transisi Menuju Demokrasi. Yogyakarta: Pustaka Pelajar.

Juergensmeyer, Mark. (1993). "The New Cold War? Religious Nationalism Confronts the Secular State". Terjemahan oleh

Noorhadi. (1998). Menentang Negara Sekuler Kebangkitan Global Nasionalisme Religius. Bandung: Mizan.

Fatwa, A. M. (2002). Satu Islam Multi Partai Membangun Integritas di Tengah Pluralitas. Bandung: Mizan.

Pilliang, Yasraf Amir. (1999). Kompas "The Perfect Crime: Hiperrealitas Timor-Timur, edisi 12 oktober.

Prayitno, Budi. (2001). What is Democracy. Terjemahan: Apakah Demokrasi itu?, United States Information Agency.

Soelaeman, M. Munandar. (2001). Ilmu Sosial dasar Teori dan Konsep Ilmu Sosial. Bandung: Refika Aditama.

Tim ICCE Uin Jakarta. (2007). Pendidikan Kewarganegaraan (Civic Education), Demokrasi Hak Asasi manusia, dan Masyarakat Madani. Jakarta: Kencana

Yusanto, Ismail. (1998). Islam Ideologi: Refleksi Cendekiawan Muda. Bangil: Al-Izzah. 